\title{
PENYELESAIAN SENGKETA HARTA BERSAMA DENGAN HARTA BAWAAN KETIKA TERJADI PERCERAIAN
}

\author{
John Kenedi \\ IAIN Bengkulu \\ johnkenedi297@yahoo.com
}

\begin{abstract}
The Marriage Agreement functions as a solution to anticipate or avoid injustice in the trial process in the court of the distribution of property, if there is a dispute between husband and wife. Conflicts over the distribution of inheritance sometimes can not be resolved by mediation efforts, even after being processed in the first court (religious court), continues into the court of appeal and cassation. Benefits of a Marriage Agreement in the Settlement of Default Assets, to assist the panel of judges adjudicating a case of inheritance disputes in making the right decision in divorce cases. If a case does not occur, the agreement is useful for separating the status between shared assets and property. If a case / dispute occurs, the marriage agreement is available
\end{abstract}

Keywords: Disputes, Joint Assets, Divorce.

Abstrak. Perjanjian Perkawinan berfungsi salah satu solusi untuk mengantisipasi atau menghindari terjadinya ketidakadilan dalam proses persidangan di pengadilan terhadap pembagian harta bawaan, apabila terjadi sengketa antara suami dan isteri. Konflik pembagian harta bawaan ini terkadang tidak dapat ditempuh dengan upaya mediasi, bahkan setelah diproses di pengadilan tingkat pertama (pengadilan agama), terus berlanjut ke dalam proses peradilan tingkat banding dan kasasi. Manfaat Perjanjian Perkawinan Dalam Penyelesaian Sengketa Harta Bawaan, untuk membantu majelis hakim yang mengadili suatu perkara sengketa harta bawaan dalam mengambil keputusan yang tepat dalam perkara perceraian. Bila tidak terjadi perkara, perjanjian tersebut berguna untuk memisahkan status antara harta bersama dengan harta bawaan. Bila terjadi perkara/sengketa maka perjanjian perkawinan tersebut dapat dijadikan alat bukti kepemilikan objek yang disengketakan (harta bawaan).

Kata Kunci: Sengketa, Harta Bersama, Perceraian.

\section{Pendahuluan}

Menurut Kamus Hukum, perjanjian perkawinan (Humljks Voor Waarden), adalah perjanjian kawin, dimana diperjanjikan hal-hal yang mengenyampingkan keharusan dalam KUHPerdata dengan syarat bahwa penyimpangan itu tidak 
menyalahi tata tertib umum, dan tata susila yang baik. Misalnya pemisahan harta perkawinan. ${ }^{1}$

Pada dasarnya perjanjian perkawinan ini dibuat untuk kepentingan perlindungan hukum terhadap harta bawaan masing-masing suami ataupun isteri. Walaupun Undang-Undang tidak mengatur tujuan perjanjian dan apa saja yang dapat diperjanjikan, segalanya diserahkan kepada para pihak sepanjang tidak bertentangan dengan Undang-undang, agama, ketertiban umum serta kesusilaan. Sedangkan perjanjian perkawinan mulai berlaku sejak perkawinan dilangsungkan.

Keberadaan Pasal 29 Undang-Undang Nomor 1 Tahun 1974, membuka peluang bagi calon pasangan suami isteri untuk membuat perjanjian perkawinan. Pasal ini menjadi sangat penting, jika kita kaitkan dengan sosio kultur masyarakat Indonesia yang sedang merangkak menuju tatanan masyarakat maju dengan ciri utama kuatnya kesadaran akan hak dan kewajiban.

Pergeseran tata nilai di masyarakat telah berhasil merubah persepsi masyarakat dan pada gilirannya kita melihat kecenderungan kaula muda lebih mendahulukan karir daripada cepat-cepat mengikatkan diri dalam lembaga perkawinan. Biasanya semakin tinggi karir seseorang, maka semakin banyak pertimbangan untuk memilih pasangan hidup, dari soal kelangsungan karir sampai soal keamanan harta bawaan yang selama ini telah diperoleh, dan tidak tertutup kemungkinan untuk mengamankan hal-hal tersebut di atas, perjanjian perkawinan menjadi alternatif yang banyak diminati pasangan calon suami isteri di masa depan.

Mencermati keberadaan perjanjian perkawinan itu kadangkala tidak dipikirkan oleh calon pasangan suami isteri yang akan melangsungkan perkawinan, hal ini tidak terlepas adanya komitmen mereka terhadap lembaga perkawinan itu sebagai sesuatu yang sakral atau suci yang dipertahankan sampai akhir ayat. Sehingga mereka berpikir bahwa perkawinan itu selamanya, artinya tidak berpikir sedikitpun oleh mereka bahwa suatu saat nanti perceraian mungkin saja terjadi. Namun sebahagian calon suami isteri sudah berpikir sebaliknya oleh sebab itu persoalan harta bawaan ini sudah diantisipasi dengan membuat perjanjian perkawinan yang disahkan oleh pegawai pencatat nikah atau pejabat pencatat perkawinan lainnya.

Adapun konsekuensi disahkannya perjanjian perkawinan itu, maka mengikat terhadap kedua belah pihak (suami isteri). Kemudian akibat hukumnya jika perjanjian perkawinan itu tidak dilaksanakan atau terjadi pelanggaran, maka secara otomatis memberi hak kepada salah satu pihak untuk melakukan gugatan. Hal ini ditegaskan dalam Pasal 51 Kompilasi Hukum Islam, yaitu pelanggaran perjanjian perkawinan memberi hak kepada isteri untuk meminta pembatalan nikah atau mengajukannya sebagai alasan gugatan perceraian ke pengadilan agama.

${ }^{1}$ Jct. Simorangkir, Kamus Hukum, Aditya Bakti, Bandung, 2000, hlm. 70. 
Keberadaan perjanjian perkawinan seringkali luput dari perhatian karena mereka sering menganggap bahwa perkawinan adalah suatu perbuatan yang suci sehingga tidak lazim dan dianggap tidak biasa, kasar, materialistik, juga egois, tidak etis, dan tidak sesuai dengan adat timur dan lain sebagainya. ${ }^{2}$ Perjanjian perkawinan sebenarnya berguna untuk acuan jika suatu saat timbul konflik, meski semua pasangan suami isteri tidak menghendaki konflik itu akan datang. Ketika pasangan suami isteri harus bercerai, perjanjian perkawinan juga dapat dijadikan rujukan sehingga masing-masing mengetahui hak dan kewajibannya.

Bertitik tolak dari keterangan yang dikemukakan di atas, dengan terjadinya ikatan perkawinan, maka pasangan suami isteri itu biasanya mempunyai harta, yaitu disebut dengan harta dalam perkawinan. "Sedangkan harta dalam perkawinan ini terdiri dari harta bawaan dan harta pencarian, harta bawaan adalah harta yang diperoleh sebelum terjadinya perkawinan dan harta pencarian adalah harta yang diperoleh suami isteri bersama-sama selama perkawinan". 3

Keberadaan harta pencarian dan harta bawaan dalam perkawinan akan menjadi persoalan dikemudian hari, apabila suami isteri tersebut tidak membuat perjanjian perkawinan, terlepas dari pihak suami atau isteri yang paling banyak penghasilannya. Oleh karena itu lain halnya jika suami isteri itu telah membuat perjanjian perkawinan, maka dapat saja harta pencarian itu dikuasai oleh masing-masing pihak atau disatukan sesuai dengan ikhtikadnya.

Berkenaan dengan kedudukan harta bawaan ini, sering menjadi persoalan yang cukup rumit, seperti halnya dalam kasus perceraian yang berakibat terhadap pembagian harta bawaan, dimana ada salah satu pihak merasa dirugikan karena ia merasa bahwa sebagian besar harta bawaan itu merupakan hasil keringat sendiri. Sedangkan pasangannya (isterinya) hanya sebagai ibu rumah tangga. Sebaliknya isteri merasa diperlakukan tidak adil, ia merasa bahwa sebagian besar kebutuhan rumah tangga itu ia yang memenuhinya, sedangkan suaminya hanya pegawai biasa dengan penghasilan hanya cukup untuk makan saja, dimana harta bawaan akan dibagi dua antara suami isteri tersebut.

Dengan adanya kondisi seperti ini, tentunya keberadaan perjanjian perkawinan merupakan salah satu solusi untuk mengantisipasi atau menghindari terjadinya ketidakadilan dalam proses persidangan pengadilan terhadap pembagian harta bawaan antara suami isteri. Konflik pembagian harta bawaan ini terkadang tidak dapat ditempuh dengan upaya mediasi, bahkan setelah diproses pada pengadilan tingkat pertama (pengadilan agama), terus berlanjut ke dalam proses peradilan tingkat banding dan kasasi.

\section{Hasil dan Pembahasan}

2 Tina Mariam, Pentingnya Perjanjian Perkawinan, http://bloger/blogspot.com, diakses, Rabu, 14 Pebruari 2016.

${ }^{3}$ Hilman Hadikusuma, Hukum Perkawinan Nasional. Rineka Cipta ,Jakarta, 1997, hlm. 157 
Perkataan harta sering kali diidentikkan dengan perkataan benda, dimana yang dipandang harta hanyalah sesuatu yang bersifat benda itu sendiri. Istilah harta dalam Bahasa Arab dikenal dengan perkataan "mal", jamaknya "amwal", yang kalau diartikan ke dalam Bahasa Indonesia adalah "harta benda".

Pengertian benda menurut bahasa adalah "segala sesuatu yang dimiliki atau segala sesuatu yang disimpan (dengan perbuatan) oleh manusia dengan maksud untuk disendirikan dari lainnya. ${ }^{5}$

Kemudian pengertian benda menurut pasal 499 Burgerlijk Wetboek (B.W) adalah tiap-tiap barang dan tiap-tiap hak yang dapat dikuasai oleh hak milik. Jadi yang dimaksud dengan benda adalah segala sesuatu yang menjadi objek hak milik, dan dapat dialihkan, diperdagangkan serta diwariskan kepada pihak lain.Sedangkan pengertian harta menurut istilah,ada beberapa pendapat :

1. Menurut Ibnu Abini, harta adalah sesuatu yang disenangi naluri dan (mungkin) dapat disimpan untuk waktu diperlukannya.

2. Menurut Ahmad Abu Zorqa', harta adalah semua wujud materi yang mempunyai nilai dan beredar di kalangan manusia.

3. Sedangkan menurut Muhammad Mustafah Syalabi, harta, adalah yang mungkin dapat dikuasai dan atau dapat disimpan serta dapat diambil manfaatnya menurut kebiasaan. ${ }^{6}$

Dari beberapa pengertian tentang harta yang telah dikemukakan di atas, maka dapat disimpulkan bahwa harta merupakan sesuatu yang dapat dikuasai dan disimpan serta dapat dimanfaatkan, untuk kehidupan manusia di dunia ini. Dengan demikian harta atau benda merupakan keperluan hidup yang amat penting dan sebagian besar yang beredar dalam pergaulan hidup.

Kemudian di dalam hadis Ibnu Hibbar dan Ibnu Majjah.

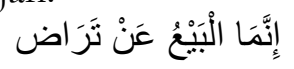

\section{Artinya : Jual beli itu banya sah dengan saling suka sama suka.}

Berdasarkan keterangan yang dikemukakan di atas, maka dapat dipahami bahwa manusia dilarang memiliki barang atau harta yang tidak halal sebagai penambah kekayaannya, tetapi hendaknya dilakukan dengan jalan transaksi jual beli secara penuh kerelaan, tanpa merugikan salah satu pihak.

Jual beli sebagai suatu perikatan akan menimbulkan hak dan kewajiban para pihak (penjual dan pembeli) setelah terjadi kata sepakat. Hak dan kewajiban itu diwujudkan dengan pemindahan hak milik masing- masing pihak. Sedangkan kata sepakat yang terjadi merupakan pernyataan masing-masing pihak sebelum memindahkan hak milik dilakukan dan disebut "Ijab dan Qabul". Menurut Amir Syarifuddin, Ijab dan Qabul adalah "suatu ucapan penyerahan hak milik di satu pihak dan ucapan penerimaan di pihak lain, adanya ijab dan qabul

\footnotetext{
4 AW. Munawir, Kamus Babasa Arab, Predana, Jakarta, 1992, hlm 1465.

5 Masduha Abdurahman, Asas-Asas Hukum Perdata Islam, Ereca, Bandung, 1992, hlm 43.

${ }_{6} \mathrm{Ibid}, \mathrm{hlm} 45$.

7 Abu Bakar Muhammad, Subulussalam, Diponogoro, Bandung, 1995, hlm. 12.
} 
dalam transaksi jual beli merupakan indikasi adanya rasa suka sama suka dari pihak-pihak yang mengadakan transaksi. ${ }^{8}$

Memperhatikan kedudukan ijab dan qabul dalam suatu transaksi, merupakan bentuk indikasi yang menyatakan tentang adanya rasa suka sama suka. Namun demikian, dengan kemajuan zaman dan perkembangan perekonomian dimana terkadang ijab qabul itu hanya dilakukan secara tertulis bahkan antara para pihak itu yang melakukan transaksi jual beli itu tidak bertemu secara langsung, tetapi ijab qabul seperti ini tetap sah. Dalam hal ini dikatakan oleh Amir Syarifuddin.

"Ijab qabul adalah salah satu bentuk indikasi yang menyatakan atau meyakinkan tentang adanya rasa suka sama suka. Bila pada waktu ini kita dapat menemukan cara lain yang dapat ditempatkan sebagai indikasi, seperti saling mengangguk atau saling menandatangani suatu dokumen, maka yang demikian telah memenuhi unsur suatu transaksi. Umpamanya transaksi jual beli di supermarket, pembeli telah menyerahkan uang dan penjual melalui petugasnya di counter telah memberikan slip tanda terima, sahkal jual beli itu".?

Kemudian cara memperoleh hak kebendaan menurut pasal 584 Burgerlijk Wetboek (B.W) adalah:

1. Pemilikan

2. Perlekatan

3. Daluwarsa

4. Pewarisan

5. Penyerahan ${ }^{10}$

Dari rumusan masalah 584 Burgerlijk Wetboek (B.W) di atas akan penulis uraikan sebagai berikut:

1. Pemilikan

Benda yang tidak ada pemiliknya (res nullius) kemudian ditemukan dan diakui oleh orang yang menemukannya sebagai miliknya. Orang yang mengakui tersebut memperoleh hak milik atas benda itu. Contohnya menangkap ikan di sungai atau di laut, berburu rusa di hutan bebas, memperoleh intan dari tempat penggalian bebas.

\section{Perlekatan}

Orang yang membeli seekor sapi yang sedang bunting kemudian sapi itu melahirkan anak. Pemilik sapi tersebut memperoleh hak milik atas anak sapi yang baru lahir itu. Tumbuhan di atas tanah pekarangan dinyatakan sebagai benda ikutan dari tanah pekarangan itu, orang yang membeli pekarangan tersebut berhak pula atas tanaman di atas pekarangan itu karena ikutan.

3. Daluwarsa

Hak kebendaan diperoleh karena daluwarsa (lampau waktu). Daluwarsa benda bergerak dan tidak bergerak tidak sama, setiap orang yang menguasai

\footnotetext{
8 Amir Syarifudin, Garis-Garis Besar Piqih, Sinar Grafika, Jakarta, 2003, hlm. 195.

${ }^{9}$ Ibid, blm 196

${ }^{10}$ Lihat Pasal 584 Kita Undang- Undang Hukum Perdata (BW)
} 
benda bergerak, misalnya karena penemuan di jalan hak milik diperoleh setelah lampau waktu tiga tahun sejak dia menguasai benda bergerak itu (pasal 1977 ayat (2) B.W), untuk benda tidak bergerak daluwarsa adalah dua puluh tahun dalam ada alas hak dan tiga puluh tahun dalam hal tidak ada alas hak.

\section{Pewarisan}

Hak kebendaan diperoleh karena pewarisan menurut hukum waris yang berlaku, ada tiga macam hukum waris yaitu hukum waris adat, hukum waris Islam dan hukum waris KUH Perdata (BW). Pewarisan dinyatakan terbuka bagi ahli waris untuk memperoleh hak waris sejak almarhum pemilik harta warisan itu meninggal dunia.

5. Penyerahan

Hak kebendaan diperoleh karena penyerahan berdasarkan pada alas hak (rechstitel) tertentu, misalnya jual beli, hibah, dan pewarisan. Karena ada penyerahan itu, hak kebendaan atas benda berpindah kepada pihak penerima hak. ${ }^{11}$

a. Harta Kekayaan Dalam Perkawinan.

Harta bersama dalam perkawinan adalah harta yang diperoleh suami istri salama dalam ikatan perkawinan. Hai ini diatur dalam pasal 35 undang-undang nomor 1 tahun 1974 tentang perkawinan, yaitu sebagai berikut:

1. Harta Bersama

Undang-undang Nomor 1 Tahun 1974 tentang Perkawinan (UUP) pasal 1 huruf (f) menerangkan bahwa harta benda yang diperoleh selama perkawinan menjadi harta bersama. Kompilasi Hukum Islam (KHI) memberikan pengertian bahwa harta bersama atau syirkah yaitu harta yang diperoleh sendiri-sendiri atau bersama-sama suami isteri selama perkawinan tanpa mempersoalkan terdaftar atas nama siapa pun. ${ }^{12}$

Dari pengertian pasal 35 diatas dapat dipahami bahwa segala harta yang diperoleh selama dalam ikatan perkawinan diluar harta warisan, hibah dan hadiah. Karena itu, harta yang diperoleh suami atau istri berdasarkan uahanya masing-masing merupakan milik bersama suami istri.

Lain halnya harta yang diperoleh masing-masing suami dan istri sebelum akad nikah, yaitu harta asal, atau harta bawaan, harta asal itu, akan diwarisi oleh masing-masing keluarganya bila pasangan suami istri itu meninggal dan tidak mempunyai anak. hal ini diatur dalam firman Allah dalam surat An-nisaa' ayat 32 sebagai berikut:

artinya : Dan janganlah kamu iri hati terbadap apa yang dikaruniakan Allah kepada sebahagian kamu lebib banyak dari sebahagian yang lain. (karena) bagi orang laki-laki ada bahagian dari pada apa yang mereka usabakan, dan bagi para wanita (pun) ada bahagian dari apa yang mereka usahakan, dan mohonlah kepada Allah sebagian dari karunia-Nya. Sesunggubnya Allah Maha mengetahui segala sesuatu.

11 Abdul Kadir Muhammad, Hukum Perdata Indonesia, Rineka Cipta, Jakarta, 2010, hlm 210

12 Sayuti Thalib, Hukum Kekeluargaan Indonesia Berlaku Bagi Umat Islam, Universitas Indonesia Press, Jakarta, 1981, hlm. 92. 
Isyarat dan penegasan ayat tersebut dijelaskan lebih lanjut dalam kompilasi Hukum Islam Pasal 85.86.87. yaitu sebagai berikut ${ }^{13}$ :

Pasal 85 KHI:

Adanya harta bersama dalam perkawinan itu tidak menutup kemungkinan adanya harta milik masing-masing suami atau istri.

Pasal 86 KHI:

Ayat (1): Pada dasarnya tidak ada percampuran antara harta suami dan harta istri karena perkawinan.

Ayat (2): Harta istri tetap menjadi hak istri dan dikuasai penuh olehnya, demikian juga harta suami tetap menjadi hak suami dan dikuasai penuh olehnya.

Pasal $87 \mathrm{KHI}$ :

Ayat (1): Harta bawaan dari masing-masing sebagai hadiah atau warisan adalah dibawah pengusaan masing-masing sepanjang para pihak tidak menentukan lain dalam perjanjian perkawinan.

Ayat(2): Suami dan istri mempunyai hak sepenuhnya untuk melakukan perbuatan hukum atas harta masing-msing berupa hibah, hadiah, Shodaqah, atau lainnya.

Penggunaan harta bersama suami istri atau harta dalam perkawinan, di atur dalam Pasal 36 ayat 1 . Undang-undang perkawinan, yang menyatakan bahwa ${ }^{14}$ :

Mengenai harta bersama suami atau istri dapat bertindak atas persetujuan kedua belah pihak.

Lain halnya penggunaan harta asal, atau harta bawaan penggunaanya di atur dalam pasal 36 ayat $\{2\}$ Undang-undang tentang perkawinan, yang menyatakan bahwa menjelasakan tentang hak suami atau istri untuk mebelanjakan harta bawaan masing-masing.

Pasal 89 KHI:

Suami bertanggung jawab menjaga harta bersama, harta istri, maupun harta sendiri.

Pasal 90 KHI :

Istri turut bertanggung jawab menjaga harta bersama, maupun harta suami yang ada padanya.

Dari pengaturan harta tesebut, baik harta bersama maupun harta asal/harta bawaan berdasarkan firman Allah urat An-nisaa ayat 34 yang berbunyi sebagai berikut :

aritnya : Kaum laki-laki itu adalah pemimpin bagi kaum wanita, oleh Karena Allah Telah melebibkan sebahagian mereka (laki-laki) atas sebahagian yang lain (wanita), dan Karena mereka (laki-laki) Telah menafkahkan sebagian dari harta mereka. sebab itu Maka wanita yang saleh, ialah yang taat kepada Allah lagi memelihara diri[289] ketikea suaminya tidak ada, oleh Karena Allah Telah memelihara \{mereka\}.

\footnotetext{
${ }^{13}$ Lihat Kompilasi Hukum Islam Kususnya Pasal 85, 86 dan 87.

${ }^{14}$ Lihat Pasal 36 ayat (1) Undang-Undang Nomor : 1 Tahun 1974 Tentang Perkawinan.
} 


\section{Harta Bawaan.}

Menurut ketentuan Pasal 35 Undang-Undang Nomor 1 Tahun 1974 ditegaskan:

(1) Harta benda yang diperoleh selama perkawinan menjadi harta bersama.

(2) Harta bawaan dari masing-masing suami dan isteri dan harta benda yang diperoleh masing-masing sebagai hadiah atau warisan, adalah dibawah penguasaan masing-masing sepanjang para pihak tidak menentukan lain. ${ }^{15}$

Kemudian berkenaan dengan harta bawaan tersebut, menurut Hilman ${ }^{16}$ adalah harta yang dibawa masing-masing suami isteri ke dalam ikatan perkawinan, mungkin berupa harta hasil jerih payahnya sendiri, dan mungkin juga berupa harta hadiah atau harta warisan yang didapat masing-masing suami isteri sebelum atau sesudah perkawinan.

Ada perbedaan yang sangat prinsip perjanjian perkawinan mengenai harta kekayaan antara ketentuan yang diatur dalam UUP dan KUHPdt. Dalam UUP apabila tidak diadakan perjanjian sebelum perkawinan dilangsungkan maka maka harta bawaan suami atau harta bawaan isteri tetap dikuasai oleh masingmasing pihak (pasal 35 ayat 2 UUP). Sebaliknya dalam KUHPdt apabila tidak diadakan perjanjian sebelum perkawinan berlangsung maka harta bawaan masing-masing pihak otomatis menjadi harta bersama. ${ }^{17}$

c. Perjanjian Perkawinan dalam Penyelesaian Sengketa Harta Bawaan.

Ketentuan mengenai harta dalam perkawinan diatur dalam pasal 35 Undang-Undang Nomor 1 Tahun 1974 ditegaskan:

(1) Harta benda yang diperoleh selama perkawinan menjadi harta bersama.

(2) Harta bawaan dari masing-masing suami dan isteri dan harta benda yang diperoleh masing-masing sebagai hadiah atau warisan, adalah dibawah penguasaan masing-masing sepanjang para pihak tidak menentukan lain. ${ }^{18}$

Menurut Hilman ${ }^{19}$, harta bawaan adalah harta yang dibawa masing-masing suami isteri ke dalam ikatan perkawinan, mungkin berupa harta hasil jerih payahnya sendiri, dan mungkin juga berupa harta hadiah atau harta warisan yang didapat masing-masing suami isteri sebelum atau sesudah perkawinan.

Di masyarakat dalam prakteknya harta bawaan ini dapat dibedakan beberapa macam, yaitu:

a. Harta peninggalan

Harta peninggalan adalah harta atau barang-barang yang dibawa oleh suami atau isteri ke dalam perkawinan yang berasal dari peninggalan orang tua untuk diteruskan penguasaan dan pengaturan serta pemanfaatannya guna kepentingan para ahli waris.

b. Harta warisan.

\footnotetext{
${ }^{15}$ Lihat Pasal 35 Undang-Undang Nomor : 1 Tahun 1974 Tentang Perkawinan.

16Hilman Hadikusuma, Hukum Waris Adat, Alumni, Bandung, 1990, hlm 123.

${ }^{17}$ Abdul Kadir Muhammad, Hukum Perdata.....Op.Cit, hlm 89.

${ }^{18}$ Lihat Pasal 35 Undang-Undang Nomor 1 Tahun 1974 Tentang Perkawinan.

${ }^{19}$ Hilman Hadikusuma, Hukum Waris....Op.Cit, hlm 123.
} 
Harta warisan yang dimaksud adalah harta atau barang-barang yang dibawa oleh suami atau isteri ke dalam perkawinan yang berasal dari harta warisan orang tua untuk dikuasai dan dimiliki secara perorangan.

c. Harta hibah

Harta hibah adalah harta atau barang-barang yang dibawa oleh suami atau isteri ke dalam perkawinan yang berasal dari hibah anggota kerabat.

d. Harta pemberian atau hadiah

Harta pemberian ini adalah harta atau barang-barang yang dibawa oleh suami atau isteri ke dalam perkawinan yang berasal dari pemberian atau hadiah para anggota kerabat dan mungkin juga orang lain karena hubungan baik. ${ }^{20}$

Dengan demikian dapat dipahami bahwa harta bawaan ini, adalah harta atau barang-barang kepunyaan masing-masing suami isteri yang dibawa ke dalam perkawinan dan dikuasai secara penuh oleh masing-masing pihak. Dengan perkataan lain walaupun harta bawaan tersebut dibawa ke dalam perkawinan, tetapi bukan merupakan bagian harta bersama dalam perkawinan. Sehingga salah satu pihak tidak dapat mengambil atau memanfaatkan harta atau barang bawaan tersebut tanpa seizin suami atau isteri yang memiliki barang bawaan itu, kecuali hal tersebut dijanjikan lain.

Kemudian di dalam ajaran Islam berkenaan dengan harta bawaan dari isteri, pihak suami tidak boleh menggunakannya atau memanfaatkannya walaupun untuk memenuhi kebutuhan hidup dalam rumah tangga. Dengan demikian walaupun harta bawaan isteri itu masuk dalam perkawinan, bukan berarti harta bawaan tersebut menjadi bagian dari harta bersama. Sebagaimana dikatakan oleh Soemiyati" " "pada dasarnya menurut hukum Islam harta suami isteri itu terpisah, jadi masing-masing pihak mempunyai hak untuk menggunakan atau membelanjakan hartanya dengan sepenuhnya tanpa boleh diganggu oleh pihak lain".

Dengan terjadinya ikatan perkawinan mengkondisikan adanya harta, diantaranya harta bawaan antara suami isteri. Ketentuan tentang harta bawaan harus jelas diketahui sebelum perkawinan akan dilangsungkan. Membahas masalah harta bawaan sangatlah penting dalam kehidupan rumah tangga agar dikemudian hari hal-hal yang tidak diinginkan dapat dihindari. Penyelesaian masalah harta bawaan jarang diselesaikan secara tuntas oleh pasangan suami isteri, hal ini dikatakan oleh Hakim, Pak Nadhifah. ${ }^{22}$

Permasalahan harta bawaan ini pada umumnya banyak terjadi pada calon suami isteri yang telah mempunyai harta atau kekayaan sebelum mereka kawin, seperti pengusaha muda, dokter, kontraktor dan lain sebagainya, dengan perkataan lain semasa mereka belum berkeluarga mereka telah mandiri dan tidak tergantung lagi dengan bantuan orang tua. Dengan adanya harta bawaan

\footnotetext{
${ }^{20}$ Ibid, hlm 160.

${ }^{21}$ Soemiyati, Hukum Perkawinnan Menurut Hukum Islam dan Undang-Undang Nomor 1 Tabun 1974, Liberty, Yogjakarta, 1996, hlm 98.

${ }^{22}$ Skripsi Septi Maryani, Penyelesaian Sengketa Perjanjian Perkawinan Tentang Harta Bawaan (Studi Kasus di Pengadilan Agama Kelas 1 A Bengkulu Tabun 2012.
} 
seperti ini, jika tidak dibuat perjanjian perkawinan lambat laun akan menjadi harta bersama. Kondisi seperti ini jika suami isteri dapat mempertahankan perkawinannya sampai akhir hayat tidak menjadi persoalan, tetapi jika terjadi perceraian maka akan mengalami kesulitan untuk menyelesaikannya.

Kemudian hal senada juga dikemukakan oleh Nadimah Hakim, Pengadilan Agama Bengkulu, ${ }^{23}$

Pada dasarnya harta bawaan ini dapat diperoleh, baik melalui hasil pencarian sendiri oleh calon suami isteri maupun dari orang tua. Keberadaan harta bawaan ini bagi pasangan suami isteri di awal perkawinan atau pada saat perkawinan berlangsung terkadang tidak menjadi persoalan, karena mereka telah berkomitmen semua harta masing-masing pihak adalah harta bersama, dan mereka tidak memikirkan akan terjadinya perceraian. Dengan adanya komitmen seperti ini, jika terjadi perceraian hakim akan mengalami kesulitan untuk mengidentifikasi harta bawaan suami isteri tersebut. Oleh karena itu lain halnya jika suami isteri tersebut membuat perjanjian perkawinan, maka persoalan atau sengketa harta bawaan tidak akan terjadi.

Berdasarkan keterangan yang telah dipaparkan di atas, dapat dipahami bahwa, sebagian besar pasangan suami isteri ini di dalam menggabungkan atau menyatukan harta bawaan, tanpa diikuti oleh ketentuan yang jelas seperti perjanjian perkawinan. Pasangan suami isteri itu merasa tidak etis untuk membuat perjanjian.

Hal ini secara tidak langsung sudah berlaku prinsip ketentuan yang diatur dalam KUHPdt. dimana menyangkut masalah harta bawaan apabila tidak diadakan perjanjian sebelum perkawinan berlangsung maka harta bawaan masing-masing pihak otomatis menjadi harta bersama. ${ }^{24}$

Dalam proses persidangan di Pengadilan salah satu cara untuk mengetahui atau menyatakan sesuatu itu adalah miliknya adalah dengan alat bukti. Oleh karena itu untuk membuktikan harta bawaan kepunyaan suami atau isteri, salah satu pihak harus membuktikan bahwa barang itu miliknya. Demikian juga halnya jika salah satu pihak menyatakan bahwa mereka telah membuat perjanjian tentang harta bawaan, maka mereka harus menunjukkan bukti tentang adanya perjanjian.

Jadi perjanjian perkawinan tentang pemisahan harta bawaan itu sangat penting dalam menyelesaikan sengketa harta bawaan bila terjadi perceraian walaupun dalam UUP dinyatakan apabila tidak dijanjikan maka tetap menjadi kekuasaan masing-masing pihak namun kadangkala hakim kesulitan untuk menemukan alat bukti bahwa harta tersebut merupakan harta bawaan kecuali masing-masing pihak dapat membuktikannya.

d. Tata Cara Pembuatan Perjanjian Perkawinan

\footnotetext{
23 Ibid

${ }^{24}$ Abdul Kadir Muhammad, Hukum Harta Kekayaan, PT.Citra Aditya, Bandung, 1994,
} hlm. 89 . 
Pada umumnya tidak banyak orang tahu bahwa pada saat atau sebelum perkawinan dilangsungkan, calon suami atau isteri dapat membuat suatu perjanjian perkawinan. Padahal perjanjian perkawinan sangat penting untuk melindungi dan memperjelas hak dan kewajiban kedua belah pihak, baik selama perkawinan berlangsung maupun akibat-akibat hukum setelah perkawinan putus karena perceraian atau kematian.

Sebetulnya perjanjian perkawinan atau perjanjian pra nikah ini sering diucapkan oleh calon pasangan suami isteri, tetapi hanya sebatas di mulut saja tanpa ditindaklanjuti dengan perjanjian secara tertulis. Dalam hal ini dikatakan oleh Ahmad Sahil hakim Pengadilan Agama Bengkulu ${ }^{25}$.

Berkenaan dengan perjanjian perkawinan ini, untuk saat ini banyak dilakukan hanya secara lisan atau baru sebatas ucapan di mulut saja, artinya pasangan suami isteri itu tidak menuangkan perjanjian mereka secara tertulis. Sehingga perjanjian perkawinan yang mereka ucapkan itu tidak mempunyai kekuatan hukum dan tidak mengikat terhadap para pihak. Hal ini mereka lakukan dikarenakan ketidaktahuan mereka bahwa perjanjian perkawinan itu harus dituangkan secara tertulis dan disahkan oleh Pegawai Pencatat Nikah.

Kemudian berkenaan dengan tata cara pembuatan perjanjian perkawinan adalah sebagai berikut :

1. Bagi pasangan calon suami isteri yang akan membuat perjanjian perkawinan harus mematuhi atau berpedoman kepada Undang-Undang Nomor 1 Tahun 1974 pasal 29 dan Kompilasi Hukum Islam pasal 45 sampai dengan pasal 52. Hal ini berarti apabila calon pasangan suami isteri membuat perjanjian perkawinan melanggar ketentuan dalam Undang-Undang Nomor 1 Tahun 1974 dan Kompilasi Hukum Islam, maka perjanjian perkawinan itu tidak dapat disahkan oleh Pegawai Pencatat Nikah.

2. Perjanjian perkawinan harus dibuat sebelum pasangan suami isteri melangsungkan pernikahan dan dalam perjanjian perkawinan itu calon pasangan suami isteri dapat merumuskan beberapa ketentuan yang disepakati, diantaranya pengaturan tentang harta bawaan, harta pencaharian dan pengaturan hal-hal di luar harta kekayaan.

3. Setelah calon pasangan suami isteri telah selesai merumuskan isi perjanjian perkawinan secara tertulis dengan persetujuan bersama, maka harus disahkan oleh Pegawai Pencatat Nikah. Kedudukan pengesahan perjanjian perkawinan oleh Pegawai Pencatat Nikah, merupakan syarat administrasi. Oleh karena itu apabila tidak disahkan, maka perjanjian perkawinan itu tidak mempunyai kekuatan hukum.

4. Perjanjian perkawinan berlaku sejak perkawinan dilangsungkan, perjanjian perkawinan tersebut tidak dapat dirubah, kecuali ada persetujuan dari kedua belah pihak, dan selama perubahan tersebut tidak merugikan pihak ketiga. Hal ini berarti perjanjian perkawinan hanya dapat dirubah jika ada kesepakatan kedua belah pihak, apabila keinginan untuk merubah isi perjanjian perkawinan

${ }^{25}$ Septi Maryani, Skripsi, Loc. Cit 
itu hanya datang dari satu pihak, dan satu pihak lainnya itu tidak setuju, maka perubahan tidak sah. Nadimah Hakim, Pengadilan Agama Bengkulu. ${ }^{26}$

Berdasarkan keterangan yang telah dipaparkan di atas, maka dapat disimpulkan tentang tata cara pembuatan perjanjian perkawinan, yaitu:

1. Perjanjian perkawinan dapat dibuat:

a. Pada waktu atau sebelum perkawinan dilangsungkan

b. Perjanjian atas persetujuan bersama

c. Perjanjian dilakukan secara tertulis

d. Perjanjian disahkan oleh Pegawai Pencatat Nikah

e. Isi perjanjian juga mengikat pihak ketiga sepanjang pihak ketiga tersangkut.

2. Perjanjian perkawinan hanya dapat disahkan apabila tidak melanggar batasbatas hukum agama dan kesusilaan.

3. Perjanjian perkawinan berlaku sejak perkawinan dilangsungkan.

4. Perjanjian perkawinan dapat dirubah dengan syarat atas kesepakatan kedua belah pihak dan perubahan tersebut tidak merugikan pihak ketiga.

e. Fungsi Perjanjian Perkawinan Dalam Mengatasi Masalah Harta Bawaan Ketika Terjadi Perceraian

Di negara kita Indonesia ini, yang masih menjunjung tinggi adat ketimuran, menjadi persoalan yang sensitif ketika salah seorang calon pasangan suami isteri berniat mengajukan untuk membuat perjanjian perkawinan. Perjanjian perkawinan menjadi suatu hal yang tidak lazim dan dianggap tidak etis, tidak biasa, materiliastis, egois dan tidak sesuai dengan adat timur.

Keberadaan perjanjian perkawinan ini, sebagaimana telah disinggung pada pembahasan terdahulu bahwa keberadaan perjanjian perkawinan ini adalah berkaitan dengan harta bawaan masing-masing pihak agar bisa membedakan yang mana harta calon suami dan yang mana harta bawaan calon isteri. Sehingga harta bawaan tersebut akan berada dalam kekuasaan masing-masing pihak, dan masing-masing pihak suami isteri dapat mempergunakan harta bawaannya sesuai dengan keinginan mereka.

Pada saat terjadi putusnya perkawinan karena perceraian, maka salah satu permasalahan yang sering menjadi persengketaan adalah harta kekayaan. Dimana harta kekayaan yang akan dibagi antara suami isteri tidak mempersoalkan pihak mana yang mencari harta tersebut atau pihak mana yang paling banyak penghasilannya. Kemudian berkenaan dengan peranan perjanjian perkawinan dalam mengantisipasi masalah harta bawaan dikatakan oleh Nadimah Hakim, Pengadilan Agama Bengkulu. ${ }^{27}$

Apabila konflik dalam rumah tangga tidak bisa diselesaikan secara kekeluargaan lagi dan suami isteri itu tidak mempunyai keinginan untuk hidup bersama lagi, maka jalan yang harus ditempuh adalah bercerai yang dilakukan di Pengadilan Agama. Dalam proses perceraian yang dilakukan di Pengadilan Agama, bukan hanya untuk memutuskan perkawinan saja, tetapi juga

\footnotetext{
${ }^{26}$ Septi Maryani, Skripsi, Ibid.

${ }^{27}$ Septi Maryani, Skripsi, Ibid
} 
menyelesaikan harta kekayaan yang ada dalam perkawinan itu. Pada dasarnya keberadaan harta bawaan dalam perjanjian biasanya menjadi harta bersama, baik harta bawaan isteri maupun harta bawaan suami. Tetapi jika ada perjanjian perkawinan yang mengatur tentang keberadaan harta bawaan, maka pada saat terjadi perceraian dan pembagian harta kekayaan, maka posisi harta bawaan tidak menjadi persoalan, artinya tetap dikuasai oleh masing-masing pihak.

Sehingga keberadaan Perjanjian Perkawinan berfungsi salah satu solusi untuk mengantisipasi atau menghindari terjadinya ketidakadilan dalam proses persidangan di pengadilan terhadap pembagian harta bawaan, apabila terjadi sengketa antara suami isteri. Konflik pembagian harta bawaan ini terkadang tidak dapat ditempuh dengan upaya mediasi, bahkan setelah diproses di pengadilan tingkat pertama (pengadilan agama), terus berlanjut ke dalam proses peradilan tingkat banding dan kasasi.

Berdasarkan keterangan yang telah dikemukakan di atas, dapat dipahami bahwa masyarakat Indonesia pada umumnya dan khususnya masyarakat, masih menjunjung tinggi adat ketimuran dan memandang sebuah perkawinan itu merupakan sesuatu yang sacral dan suci. Sehingga antara suami isteri tidak mengedepankan atau mempersoalkan harta bawaan masing-masing pihak, dengan perkataan lain apa saja yang menjadi milik masing-masing pihak menjadi milik bersama.

\section{f. Peranan Hakim Dalam Menyelesaikan Harta Bawaan}

Sebagaimana telah kita ketahui bahwa keberadaan harta bawaan dalam suatu perkawinan tetap berada dalam kekuasaan masing-masing pihak atau harta bawaan tidak bersatu dengan harta bersama. Hal ini ditegaskan pada pasal 35 ayat (2) Undang-Undang Nomor 1 Tahun 1974, "harta bawaan dari masingmasing sebagai hadiah atau warisan adalah di bawah penguasaan masing-masing sepanjang para pihak tidak menentukan lain". ${ }^{28}$

Namun demikian pada kenyataannya dalam masyarakat Indonesia yang memegang teguh adat ketimuran, pada saat seseorang itu melaksanakan perkawinannya, tidak mempersoalkan keberadaan harta bawaan yang mereka miliki masing-masing.

Namun masalah tersebut muncul biasanya ketika terjadi komplik rumah tangga, dimana salah satu pihak baru mempersoalkan harta bawaannya pada saat akan dilakukan pembagian harta bersama. Sehingga biasanya hakim mengalami kesulitan dikarenakan harta bawaan tersebut telah dilebur ke dalam harta bersama.

Maka para pihak perlu membuktikan bahwa mereka mempunyai harta bawaan. Jadi suami atau isteri harus mempunyai alat bukti bahwa harta bawaan mereka telah bercampur dengan harta bersama, setelah ada alat buktinya harta bawaan tersebut akan diserahkan kepada para pihak.

Dari paparan yang telah dikemukakan di atas, dapat disimpulkan bahwa walaupun harta bawaan telah disatukan ke dalam harta bersama, tetapi tidak ada 
perjanjian perkawinan, maka hakim akan memisahkan terlebih dahulu harta bawaan itu dari harta bersama. Sebelum pemisahan harta bawaan ini dengan harta bersama, maka terlebih dahulu hakim memerintahkan kepada para pihak untuk mengajukan alat bukti tentang keberadaan harta bawaan tersebut.

\section{Penutup}

Perjanjian perkawinan berfungsi salah satu solusi untuk mengantisipasi atau menghindari terjadinya ketidakadilan dalam proses persidangan di pengadilan terhadap pembagian harta bawaan, apabila terjadi sengketa antara suami dan isteri. Konflik pembagian harta bawaan ini terkadang tidak dapat ditempuh dengan upaya mediasi, bahkan setelah diproses di pengadilan tingkat pertama (pengadilan agama), terus berlanjut ke dalam proses peradilan tingkat banding dan kasasi.

Manfaat Perjanjian Perkawinan Dalam Penyelesaian Sengketa Harta Bawaan Ketika Terjadi Perceraian

1. Untuk membantu majelis hakim yang mengadili suatu perkara sengketa harta bawaan dalam mengambil keputusan yang tepat dalam perkara perceraian.

2. Bila tidak terjadi perkara, perjanjian tersebut berguna untuk memisahkan status antara harta bersama dengan harta bawaan

3. Bila terjadi perkara/sengketa maka perjanjian perkawinan tersebut dapat dijadikan alat bukti kepemilikan objek yang disengketakan (harta bawaan).

\section{Daftar Pustaka}

Abdul Kadir Muhammad, Hukum Harta Kekayaan, PT.Citra Aditya, Bandung, 1994.

Abdul Kadir Muhammad, Hukum Perdata Indonesia, Rineka Cipta, Jakarta, 2010.

Abu Bakar Muhammad, Subulussalam, Diponogoro, Bandung, 1995.

Amir Syarifudin, Garis-Garis Besar Piqih, Sinar Grafika, Jakarta, 2003.

AW. Munawir, Kamus Bahasa Arab, Predana, Jakarta, 1992, hlm 1465.

Hilman Hadikusuma, Hukum Waris Adat, Alumni, Bandung, 1990. 1997.

Hilman Hadikusuma, Hukum Perkawinan Nasional. Rineka Cipta, Jakarta,

Jct. Simorangkir, Kamus Hukum, Aditya Bakti, Bandung, 2000. 1992.

Masduha Abdurahman, Asas-Asas Hukum Perdata Islam, Ereca, Bandung,

Kita Undang- Undang Hukum Perdata (BW).

Sayuti Thalib, Hukum Kekeluargaan Indonesia Berlaku Bagi Umat Islam, Universitas Indonesia Press, Jakarta, 1981.

Soemiyati, Hukum Perkawinnan Menurut Hukum Islam dan Undang-Undang Nomor 1 Tabun 1974, Liberty, Yogjakarta, 1996. 
106 | Manhaj: Jurnal Penelitian dan Pengabdian Masyarakat | Vol. 3 No. 1, 2018

Peraturan Perundang-undangan:

Kompilasi Hukum Islam Kususnya Pasal 85, 86 dan 87.

Undang-Undang Nomor : 1 Tahun 1974 Tentang Perkawinan.

Tina Mariam, Pentingnya Perjanjian Perkawinan,

http://bloger/blogspot.com, diakses, Rabu, 14 Pebruari 2016. 